\title{
BMJ Open Relationship between social cognitive theory constructs and self-reported condom use: assessment of behaviour in a subgroup of the Safe in the City trial
}

\author{
Margaret C Snead, ${ }^{1}$ Ann M O'Leary, ${ }^{2}$ Michele G Mandel, ${ }^{1}$ Athena P Kourtis, ${ }^{1}$ \\ Jeffrey Wiener, ${ }^{1}$ Denise J Jamieson, ${ }^{1}$ Lee Warner, ${ }^{1} \mathrm{C}$ Kevin Malotte, ${ }^{3}$ \\ Jeffrey D Klausner, ${ }^{4}$ Lydia O'Donnell, ${ }^{5}$ Cornelis A Rietmeijer, ${ }^{6}$ Andrew D Margolis ${ }^{2}$
}

To cite: Snead MC, O'Leary AM, Mandel MG, et al. Relationship between social cognitive theory constructs and self-reported condom use: assessment of behaviour in a subgroup of the Safe in the City trial. BMJ Open 2014:4:e006093. doi:10.1136/bmjopen-2014006093

- Prepublication history for this paper is available online. To view these files please visit the journal online (http://dx.doi.org/10.1136/ bmjopen-2014-006093)

Received 11 July 2014 Revised 7 October 2014 Accepted 17 November 2014

CrossMark

For numbered affiliations see end of article.

Correspondence to Dr Margaret Christine Snead; msnead@cdc.gov

\section{ABSTRACT}

Objectives: Previous studies have found social cognitive theory (SCT)-framed interventions are successful for improving condom use and reducing sexually transmitted infections (STIS). We conducted a secondary analysis of behavioural data from the Safe in the City intervention trial (2003-2005) to investigate the influence of SCT constructs on study participants' self-reported use of condoms at last intercourse.

Methods: The main trial was conducted from 2003 to 2005 at three public US STI clinics. Patients $(n=38635)$ were either shown a 'safer sex' video in the waiting room, or received the standard waiting room experience, based on their visit date. A nested behavioural assessment was administered to a subsample of study participants following their index clinic visit and again at 3 months follow-up. We used multivariable modified Poisson regression models to examine the relationships among SCT constructs (sexual self-efficacy, self-control self-efficacy, selfefficacy with most recent partner, hedonistic outcome expectancies and partner expected outcomes) and self-reported condom use at last sex act at the 3-month follow-up study visit.

Results: Of 1252 participants included in analysis, $39 \%$ reported using a condom at last sex act. Male gender, homosexual orientation and single status were significant correlates of condom use. Both unadjusted and adjusted models indicate that sexual self-efficacy (adjusted relative risk (RRa) $=1.50,95 \%$ $\mathrm{Cl} 1.23$ to 1.84 ), self-control self-efficacy (RRa $=1.67$, $95 \% \mathrm{Cl} 1.37$ to 2.04 ), self-efficacy with most recent partner (RRa $=2.56,95 \% \mathrm{Cl} 2.01$ to 3.27), more favourable hedonistic outcome expectancies ( $\mathrm{RRa}=1.83,95 \% \mathrm{Cl} 1.54$ to 2.17 ) and more favourable partner expected outcomes (RRa $=9.74$, $95 \% \mathrm{Cl} 3.21$ to 29.57 ) were significantly associated with condom use at last sex act.

Conclusions: Social cognitive skills, such as selfefficacy and partner expected outcomes, are an important aspect of condom use behaviour.

Trial registration number: clinicaltrials.gov (\#NCT00137370).

\section{Strengths and limitations of this study}

- A strength of our study is that the study sample size was large consisting of a geographically, ethnically and socioculturally diverse group of sexually transmitted infection (STI) clinic attendees.

- A strength of our study is that audio/computer assisted self-interview (A-CASI) technology was used to collect sensitive information.

- A potential limitation is that the analysis included only those participants who participated in the behavioural component of the larger Safe in the City (SITC) trial and, consequently, may not be representative of the overall patient population included in the larger trial, or generalisable to all STI clinic attendees.

\section{INTRODUCTION}

Sexually transmitted infections (STIs) affect approximately 19 million people annually in the USA. ${ }^{1}{ }^{2}$ Used consistently and correctly, condoms are an important strategy for reducing STIs and HIV. ${ }^{3}$ Several studies have demonstrated that social cognitive theory (SCT)-framed interventions are successful at improving condom use and reducing STI incidence. $^{4-8}$ SCT-framed interventions are thought to improve condom use and reduce sexual risk behaviour by improving individuals' behavioural skills and perceptions of their ability to use condoms (self-efficacy). ${ }^{8}$ Safe in the City (SITC), a 23 min STI prevention video, was such an intervention. It used an integrated theoretical approach, including core elements of SCT to achieve health behaviour change. ${ }^{9}$ While a previous multisite controlled trial demonstrated a decrease in the overall incidence of infection among the STI clinic participants who viewed the video, ${ }^{9}$ it remains unclear how the SITC 
intervention affected individuals' behaviour that led to reductions in STI incidence. In this account, we examine the question of whether SCT constructs influence sexual risk behaviours such as condom use. We used information collected from individuals who were a subgroup of clinic patients participating in the nested behavioural assessment conducted during the larger SITC trial.

\section{METHODS}

The SITC trial was conducted from 2003 to 2005, at three publicly funded STI clinics in the USA. Approximately 40000 clinic patients either viewed a theory-based intervention video while in the waiting room, or not; selection was based on their clinic visit date. ${ }^{9}$ The behavioural assessment component of the larger SITC trial was a non-randomised control trial where select clinic patients were invited to participate from the group of patients who attended clinic waiting rooms during the study period. For this analysis, we used data from a subset of participants who completed the behavioural assessment both immediately following their index clinic visit (baseline) and at 3 months follow-up. In total, 217 persons were lost to follow-up, 130 were not sexually active at follow-up, and 10 were excluded from this analysis due to incomplete or missing demographic information. The remaining 1252 participants were included in the analysis.

Participants received an incentive worth \$35-\$45 at the enrolment/baseline visit and an incentive worth $\$ 45-\$ 60$ at follow-up, depending on locality. The value of these incentives takes into account the time spent at the clinic as well as related costs of participation, such as travel to the clinic site, childcare arrangements, and work time lost.

The behavioural assessments were conducted using an audio/computer assisted self-interview (A-CASI) technology (QDS, Nova Research Company, Bethesda, Maryland). Each assessment measured sexual behaviours, condom use and psychosocial factors related to condom use (eg, condom use self-efficacy). Asked only at the 3 months follow-up visit, our primary outcome was self-reported condom use at the most recent sexual encounter. We chose this time frame (ie, last sex act) because self-reported sexual history and condom use are thought to be more reliable and less prone to recall bias when specific and recent. ${ }^{10}$ We selected SCT constructs as potential factors affecting condom use (also asked at the 3 months follow-up visit), including condom use selfefficacy, self-control self-efficacy, sexual self-efficacy, hedonistic condom outcome expectancies, expected partner reaction outcomes and also risk perception; all were asked at the 3-month follow-up visit. ${ }^{8} 1112$ For each construct, responses to the related questions were reverse-scored if necessary (such that all questions and responses were in the same direction, if negatively or positively phrased), then responses were cumulated, averaged and then recalculated to a binary variable to indicate either a positive (1) or ambivalent/negative (0) attitude towards condom use (table 1). For example, for each theoretical construct, if a respondent's average score was greater than 2 , then it was recalculated to ' 1 '. If a respondent's average score was 2 or below, then the score was recalculated to ' 0 ' to create a binary variable indicating either a positive (1) or ambivalent/negative attitude towards condom use (0). We examined models with both rescored and unscored constructs. Since the variables that were statistically significant did not change, we decided to use the binary coded variables. We assessed internal consistency for each construct and all Cronbach's $\alpha$ scores were $>0.80$.

\section{Statistical analysis}

We used counts and percentages in order to describe the sociodemographic and self-reported condom use characteristics (table 2). We constructed multivariable Poisson regression models with robust error variances to estimate the relative risks (RR) and associated 95\% CIs in order to determine if the specified SCT constructs, and demographic and intervention variables were associated with self-reported condom use at last sex act. Specifically, six models were constructed (table 1), for each SCT construct and risk perception (1=self-efficacy, $2=$ self-control self-efficacy, $3=$ sexual self-efficacy, $4=$ hedonistic outcome expectancies, $5=$ partner expected outcomes and $6=$ risk perception), and we assessed the effects of each on reported condom use at last sex act. The social cognitive constructs were evaluated as continuous for the five-point scales (data not shown) and also as dichotomous variables. The constructs were further evaluated in unadjusted models, and then again after adjusting for demographic and study-related variables (receipt of intervention, study site, age, race, gender, marital status, education and sexual orientation). Analyses were performed with SAS V.9.3 (SAS Institute Inc, Cary, North Carolina, USA).

\section{RESULTS}

\section{Participant characteristics}

Forty-nine per cent of participants were in the control arm of the study; $51 \%$ were in the intervention group. Participants were from all study sites: Denver (41\%), San Francisco (22\%) and Long Beach (37\%). Forty-two per cent of the participants were 25 years of age or younger, $30 \%$ were 26-34 years and $27 \%$ were over 35 years of age. Approximately two-thirds of the participants were male. Twenty-five per cent self-identified their race ethnicity as black non-Hispanic, $37 \%$ as white non-Hispanic, $15 \%$ as other non-Hispanic and $23 \%$ as Hispanic. Approximately three-quarters of respondents reported that they were single (table 2). Fourteen per cent of participants reported their sexual identity as homosexual, $78 \%$ as heterosexual and $8 \%$ as not sure or bisexual. 


\begin{tabular}{|c|c|c|c|c|c|c|}
\hline \multirow[b]{3}{*}{ SCT constructs } & \multirow[b]{3}{*}{ Items } & \multicolumn{5}{|c|}{ Responses } \\
\hline & & \multicolumn{3}{|c|}{$\begin{array}{l}\text { Strongly } \\
\text { disagree }\end{array}$} & \multicolumn{2}{|c|}{$\begin{array}{r}\text { Strongly } \\
\text { agree }\end{array}$} \\
\hline & & 0 & 1 & 2 & 3 & 4 \\
\hline \multirow{5}{*}{$\begin{array}{l}\text { 1. Self-efficacy (most } \\
\text { recent partner) }\end{array}$} & Can use a condom even if most recent sex partner does not want to & 0 & 1 & 2 & 3 & 4 \\
\hline & Can use a condom every time you have sex with most recent sex partner & 0 & 1 & 2 & 3 & 4 \\
\hline & $\begin{array}{l}\text { Can use a condom even if want to feel close with most recent sex } \\
\text { partner }\end{array}$ & 0 & 1 & 2 & 3 & 4 \\
\hline & $\begin{array}{l}\text { Can use condom even if you are making up with most recent sex partner } \\
\text { after a fight }\end{array}$ & 0 & 1 & 2 & 3 & 4 \\
\hline & Can use condom even high or drunk with most recent sex partner & 0 & 1 & 2 & 3 & 4 \\
\hline \multirow[t]{6}{*}{$\begin{array}{l}\text { 2. Self-control } \\
\text { self-efficacy }\end{array}$} & $\begin{array}{l}\text { I could stop having sex: } \\
\text { To get a condom even if I'm really turned on }\end{array}$ & 0 & 1 & 2 & 3 & 4 \\
\hline & If no condom was available & 0 & 1 & 2 & 3 & 4 \\
\hline & Even if it meant getting dressed and going to the store & 0 & 1 & 2 & 3 & 4 \\
\hline & Even with a really hot new partner & 0 & 1 & 2 & 3 & 4 \\
\hline & Even with someone I want to have a relationship with & 0 & 1 & 2 & 3 & 4 \\
\hline & Even with someone I am in love with & 0 & 1 & 2 & 3 & 4 \\
\hline \multirow[t]{16}{*}{ 3. Sexual self-efficacy } & I am sure that I can: & 0 & 1 & 2 & 3 & 4 \\
\hline & $\begin{array}{l}\text { Talk with partner about sexual past and our risk of getting STDs and } \\
\text { AIDS from each other }\end{array}$ & & & & & \\
\hline & $\begin{array}{l}\text { Go without sex until partner has had check up for STDs and doesn't } \\
\text { have any }\end{array}$ & 0 & 1 & 2 & 3 & 4 \\
\hline & break up with a partner who puts me at risk of getting STDs & 0 & 1 & 2 & 3 & 4 \\
\hline & Avoid having sex when I am drunk, or high on drugs & 0 & 1 & 2 & 3 & 4 \\
\hline & Get to know potential partners better before having sex with them & 0 & 1 & 2 & 3 & 4 \\
\hline & Have fewer sex partners in the next 3 months, than in the past 3 months & 0 & 1 & 2 & 3 & 4 \\
\hline & Have sex with only one partner in the next 3 months & 0 & 1 & 2 & 3 & 4 \\
\hline & Go without having sex for the next 3 months & 0 & 1 & 2 & 3 & 4 \\
\hline & Discuss using condoms with my partners & 0 & 1 & 2 & 3 & 4 \\
\hline & Keep condoms where I will have them nearby when I need them & 0 & 1 & 2 & 3 & 4 \\
\hline & Use condoms more often & 0 & 1 & 2 & 3 & 4 \\
\hline & $\begin{array}{l}\text { Use condoms until my partner has had a check-up for STDs, and } \\
\text { doesn't have any }\end{array}$ & 0 & 1 & 2 & 3 & 4 \\
\hline & $\begin{array}{l}\text { Use condoms until my partner has been tested for HIV (AIDS), and is } \\
\text { HIV negative }\end{array}$ & 0 & 1 & 2 & 3 & 4 \\
\hline & $\begin{array}{l}\text { Use a condom with my MAIN partner EVERY TIME we have vaginal or } \\
\text { anal sex }\end{array}$ & 0 & 1 & 2 & 3 & 4 \\
\hline & $\begin{array}{l}\text { Use a condom with partners OTHER THAN my main partner, EVERY } \\
\text { TIME we have vaginal or anal sex }\end{array}$ & 0 & 1 & 2 & 3 & 4 \\
\hline \multirow{4}{*}{$\begin{array}{l}\text { 4. Hedonistic } \\
\text { outcomes }\end{array}$} & Condoms ruin the mood & 0 & 1 & 2 & 3 & 4 \\
\hline & Sex doesn't feel as good when you use a condom & 0 & 1 & 2 & 3 & 4 \\
\hline & Sex with condoms doesn't feel natural & 0 & 1 & 2 & 3 & 4 \\
\hline & Using condoms breaks up the rhythm of sex & 0 & 1 & 2 & 3 & 4 \\
\hline \multirow{7}{*}{$\begin{array}{l}\text { 5. Partner expect } \\
\text { outcomes (most } \\
\text { recent partner) }\end{array}$} & $\begin{array}{l}\text { I think my most recent sex partner would: } \\
\text { Be proud of me if I asked to use condoms }\end{array}$ & 0 & 1 & 2 & 3 & 4 \\
\hline & Be supportive if I asked to use condoms & 0 & 1 & 2 & 3 & 4 \\
\hline & Appreciate it if I asked to use condoms & 0 & 1 & 2 & 3 & 4 \\
\hline & Be mad at me if I asked to use condoms & 0 & 1 & 2 & 3 & 4 \\
\hline & Break up with me if I asked to use condoms & 0 & 1 & 2 & 3 & 4 \\
\hline & Think I have other partners if I asked to use condoms & 0 & 1 & 2 & 3 & 4 \\
\hline & Be jealous if I asked to use condoms & 0 & 1 & 2 & 3 & 4 \\
\hline \multirow[t]{5}{*}{ 6. Risk perception } & $\begin{array}{l}\text { If I don't use condoms, I could get infected with an STD or HIV in the } \\
\text { next } 3 \text { months }\end{array}$ & 0 & 1 & 2 & 3 & 4 \\
\hline & Unless I change my behaviour, I am likely to get an STD or HIV & 0 & 1 & 2 & 3 & 4 \\
\hline & $\begin{array}{l}\text { If I don't reduce the number of people I have unprotected sex with, } \\
\text { I could get infected with a STD or HIV }\end{array}$ & 0 & 1 & 2 & 3 & 4 \\
\hline & $\begin{array}{l}\text { If I keep having unprotected sex with my partner(s), I could get infected } \\
\text { with a STD or HIV }\end{array}$ & 0 & 1 & 2 & 3 & 4 \\
\hline & $\begin{array}{l}\text { Sometimes I think that it's only a matter of time before I get an STD or } \\
\text { HIV }\end{array}$ & 0 & 1 & 2 & 3 & 4 \\
\hline
\end{tabular}


Table 2 Sociodemographic characteristics among participants in the 'Safe in the City' study behavioural assessment

\begin{tabular}{|c|c|c|}
\hline & $\begin{array}{l}N \\
1252\end{array}$ & $(\%)$ \\
\hline \multicolumn{3}{|l|}{ Study arm } \\
\hline Control & 614 & (49) \\
\hline Intervention & 638 & (51) \\
\hline \multicolumn{3}{|l|}{ Study site } \\
\hline Denver & 515 & (41) \\
\hline San Francisco & 280 & (22) \\
\hline Long Beach & 457 & (37) \\
\hline \multicolumn{3}{|l|}{ Age (years) } \\
\hline$\leq 25$ & 530 & $(42.3)$ \\
\hline $26-34$ & 380 & $(30.4)$ \\
\hline$\geq 35$ & 342 & $(27.3)$ \\
\hline \multicolumn{3}{|l|}{ Race/ethnicity } \\
\hline White (non-Hispanic) & 467 & (37) \\
\hline Black (non-Hispanic) & 318 & (25) \\
\hline Other (non-Hispanic) & 182 & (15) \\
\hline Hispanic & 285 & (23) \\
\hline \multicolumn{3}{|l|}{ Marital status } \\
\hline Single & 931 & $(74)$ \\
\hline Married/domestic part/cohabitating & 238 & (19) \\
\hline Separated/divorced/widowed & 82 & (7) \\
\hline \multicolumn{3}{|l|}{ Education } \\
\hline$\leq 12$ years of school & 429 & (34) \\
\hline Some college & 367 & (29) \\
\hline College degree & 283 & (23) \\
\hline Postcollege & 173 & (14) \\
\hline \multicolumn{3}{|l|}{ Gender } \\
\hline Male & 809 & (65) \\
\hline Female & 443 & (35) \\
\hline \multicolumn{3}{|l|}{ Sexual identity } \\
\hline Homosexual & 171 & $(14)$ \\
\hline Heterosexual & 973 & (78) \\
\hline Bisexual/not sure & 108 & (8) \\
\hline \multicolumn{3}{|l|}{ Used a condom at last sex act } \\
\hline No & 758 & $(61)$ \\
\hline Yes & 494 & (39) \\
\hline
\end{tabular}

The subgroup of participants in the behavioural assessment differed from all patients who attended the participating clinics during the study period (and whose records were reviewed) as they were significantly less likely to be male $(65.4 \%$ vs $69.7 \%)$; aged 25 years or older $(62.5 \%$ vs $68.9 \%)$; white non-Hispanic $(36.8 \%$ vs $45.9 \%$ ) and reside in San Francisco (35.2\% vs $51.0 \%)$.

\section{Correlates of condom use at last sex act}

Thirty-nine per cent of participants reported using a condom at last sex act (table 2). Multivariable analyses revealed that several sociodemographic variables were significantly associated with condom use at last intercourse (table 3). Being male ( $\mathrm{RR}=1.23$, 95\% CI 1.05 to 1.45$)$, single ( $\mathrm{RR}=1.64,95 \%$ CI 1.35 to 1.99 ) and self-identifying as homosexual ( $\mathrm{RR}=1.34,95 \%$ CI 1.12 to 1.60$)$ were significantly associated with condom use at last sex. All six constructs (1=self-efficacy, $2=$ self-control self-efficacy,
Table 3 Relationship between selected sociodemographic characteristics and condom use at last sex act among participants in the 'Safe in the City' study behavioural assessment

\begin{tabular}{|c|c|c|c|}
\hline $\begin{array}{l}\text { Sociodemographic } \\
\text { variables } †\end{array}$ & $\begin{array}{l}\text { Relative } \\
\text { risk }\end{array}$ & $95 \%$ & \\
\hline Age $<25$ years & 1.11 & 0.96 & 1.27 \\
\hline Black race & 1.15 & 0.98 & 1.36 \\
\hline Single & 1.64 & 1.35 & $1.99^{* * *}$ \\
\hline $\begin{array}{l}\text { Education (less than } \\
\text { college degree) }\end{array}$ & 0.90 & 0.78 & 1.04 \\
\hline Male & 1.23 & 1.05 & $1.45^{\star \star}$ \\
\hline $\begin{array}{l}\text { Sexual orientation } \\
\text { (homosexual) }\end{array}$ & 1.34 & 1.12 & $1.60^{\star \star \star}$ \\
\hline
\end{tabular}

$3=$ sexual self-efficacy, $4=$ hedonistic outcome expectancies, $5=$ partner expected outcomes and $6=$ risk perception) were significantly associated with self-reported condom use at last sex act in unadjusted models (table 4). After adjusting for the intervention arm and demographic variables, all of the construct associations remained significant, except risk perception (table 4). In particular, participants who scored positively on condom use selfefficacy with their most recent partner (eg, who indicated that they can use a condom even if the partner did not want to or even if 'high' or drunk, etc) were significantly more likely to have reported they used a condom during the last sex act ( $\mathrm{RRa}=2.56,95 \%$ CI 2.01 to 3.27 ).

Similarly, those with positive self-control self-efficacy ( $R R a=1.67,95 \%$ CI 1.37 to 2.04 ), positive sexual selfefficacy ( $\mathrm{RRa}=1.50,95 \%$ CI 1.23 to 1.84 ), more favourable hedonistic outcome expectancies, ( $\mathrm{RRa}=1.83,95 \%$ CI 1.54 to 2.17 ) or more favourable partner expected outcomes with their most recent sex partner ( $R R a=9.74$, 95\% CI 3.21 to 29.57 ) were also significantly more likely to have reported that they used a condom during the last sex act (all $\mathrm{p} \leq 0.001)$ in adjusted models.

\section{DISCUSSION}

SCT is based on the theoretical work of Bandura ${ }^{13}$ and includes conceptual components such as self-efficacy and outcome expectancies, such as an expected outcome for acquiring an STI or HIV. These conceptual components have been studied as correlates of sexual behaviour. Self-efficacy has been found to be an important correlate of self-reported condom use, ${ }^{814}$ and to mediate the effectiveness of risk-reduction interventions. ${ }^{16} 17$ Previous studies have demonstrated this especially for women ${ }^{814}$ and HIV-positive gay and bisexual men. ${ }^{17} 18$ Other conceptual components within the social cognitive theoretical framework that have been found to influence or mediate condom use are outcome expectancies and from the health belief model risk perceptions. Outcome expectancies are also a major 
Table 4 Unadjusted and adjusted social cognitive theory constructs and condom used at last sex act among participants in the safe in the city study behavioural assessment

\begin{tabular}{|c|c|c|c|c|c|c|c|c|}
\hline \multirow{3}{*}{$\frac{\text { Social cognitive theory constructs }}{\text { 1. Self-efficacy with most recent partner }}$} & \multicolumn{2}{|c|}{$\begin{array}{l}\text { Percentage } \\
\text { of condom } \\
\text { use at last } \\
\text { sex act }\end{array}$} & \multirow{2}{*}{$\begin{array}{l}\begin{array}{l}\text { Unadjusted } \\
\text { RR }\end{array} \\
2.72\end{array}$} & \multicolumn{2}{|c|}{$\begin{array}{l}\text { Confidence } \\
\text { levels }\end{array}$} & \multirow{2}{*}{$\begin{array}{l}\text { Adjusted } \mathbf{~} \\
\text { RR } \\
2.56\end{array}$} & \multicolumn{2}{|c|}{$\begin{array}{l}\text { Confidence } \\
\text { levels }\end{array}$} \\
\hline & 0 & 17 & & 2.13 & $3.48^{\star \star \star}$ & & 2.01 & $3.27^{\star * \star}$ \\
\hline & 1 & 47 & & & & & & \\
\hline \multirow{2}{*}{$\begin{array}{l}\text { 2. Self-control } \\
\text { self-efficacy }\end{array}$} & 0 & 26 & 1.72 & 1.41 & $2.10^{\star \star \star}$ & 1.67 & 1.37 & $2.04^{\star \star \star}$ \\
\hline & 1 & 44 & & & & & & \\
\hline \multirow{2}{*}{$\begin{array}{l}\text { 3. Sexual } \\
\text { self-efficacy }\end{array}$} & 0 & 29 & 1.45 & 1.18 & $1.78^{\star \star \star}$ & 1.50 & 1.23 & $1.84^{\star \star \star}$ \\
\hline & 1 & 42 & & & & & & \\
\hline \multirow[t]{2}{*}{ 4. Hedonistic outcome expectancies } & 0 & 27 & 1.73 & 1.46 & $2.06^{\star \star \star}$ & 1.83 & 1.54 & $2.17^{\star \star \star}$ \\
\hline & 1 & 46 & & & & & & \\
\hline \multirow[t]{2}{*}{ 5. Partner expected outcomes } & 0 & 4 & 11.04 & 3.63 & $33.56^{\star \star \star}$ & 9.74 & 3.21 & $29.57^{\star \star \star *}$ \\
\hline & 1 & 42 & & & & & & \\
\hline \multirow[t]{2}{*}{ 6. Risk perception } & 0 & 44 & 0.84 & 0.73 & $0.97^{*}$ & 0.88 & 0.76 & 1.02 \\
\hline & 1 & 37 & & & & & & \\
\hline
\end{tabular}

${ }^{*} \mathrm{p} \leq 0.05,{ }^{* *} \mathrm{p} \leq 0.01,{ }^{* *} \mathrm{p} \leq 0.001$.

†Adjusted for sociodemographic characteristics: study arm, study site, age, race, gender, marital status, sexual orientation and education. $\mathrm{RR}$, relative risk.

construct within other social psychological theories, such as the theory of reasoned action. ${ }^{19}$ For example, hedonistic outcome expectancies have been found to be related to both intention to use and self-reported use of condoms. ${ }^{6}{ }^{14}$ Risk perceptions have been evaluated among HIV-positive men who have sex with men (MSM), and while being on a highly active antiretroviral therapy did not increase risky behaviours, men who had low-risk perceptions reported more unprotected sex. ${ }^{20}$

All six constructs evaluated in this analysis of data from the SITC trial were significantly associated with condom use at last sexual intercourse. For all models, three sociodemographic characteristics-being male, single and of homosexual sexual orientation-were significantly associated with condom use at last sex. Such participants also scored higher on condom use selfefficacy with their most recent partner, self-control selfefficacy, sexual self-efficacy and had more positive condom use outcome expectancies as compared with their counterparts. These findings are consistent with previous reports, as described above. ${ }^{1421} 22$

A particular strength of our study is that the study sample included a geographically, ethnically and socioculturally diverse group of STI clinic attendees. However, there are some limitations. The analysis included only those participants who participated in the behavioural component of the SITC trial and, consequently, may not be representative of the overall patient population included in the larger trial, or generalisable to all STI clinic attendees. Additionally, although social desirability in responding is always a concern when collecting self-reported data on sexual risk behaviours, ${ }^{23}$ the use of A-CASI technology in the trial to collect sensitive information on the most recent act of intercourse may alleviate some of these concerns.
Independent of the SITC intervention, women and heterosexual men in particular did not seem to have social cognitive characteristics that facilitated condom use at last sex act. Rather, condom use was more influenced by the social cognitive construct scores and individual participant characteristics. It is possible that these individual sociocognitive characteristics predated any effects of the intervention, as we did not measure sociocognitive characteristics prior to the intervention; the initial assessment occurred at the end of the baseline visit where the video would have already been played while participants were waiting for their visit. This finding suggests future research directions; in particular, how best to determine the ways in which SCT-framed interventions influence specific behaviours such as condom use.

Can such interventions reshape or reinforce particular sociocognitive characteristics and thus change behaviour? Future studies should consider measuring SCT components longitudinally, that is, before, during and after an intervention so that the pathway of how such interventions affect SCT components can be clearly elucidated, particularly since SCT-framed interventions can be an important tool for decreasing rates of STIs. Prevention programmes that seek to increase condom use should consider social cognitive constructs (such as self-efficacy and partner expected outcomes) as important mediators of condom use, and they should be included along with condom provision work to increase social cognitive skills.

\section{Author affiliations}

${ }^{1}$ Division of Reproductive Health, National Center for Chronic Disease Prevention and Health Promotion, Centers for Disease Control and Prevention, Atlanta, Georgia, USA

${ }^{2}$ Division of HIV/AIDS, National Center for HIV/AIDS, Viral Hepatitis, STD, and TB Prevention, Centers for Disease Control and Prevention, Atlanta, Georgia, USA 
${ }^{3}$ California State University, Long Beach, California, USA

${ }^{4}$ UCLA David Geffen School of Medicine and Fielding School of Public Health, Los Angeles, California, USA

${ }^{5} \mathrm{EDC}$, Waltham, Massachusetts, USA

${ }^{6}$ Colorado School of Public Health, Denver, Colorado, USA

Contributors All authors participated in the interpretation of the study and drafting of the manuscript. All authors have seen and approved the final version. MCS, LW, AMO, MGM, APK, ADM, JW and DJJ participated in the design and analysis for the manuscript. LW, JDK, CAR, CKM and LO contributed to the overall study design and concept. JDK, CAR and CKM participated in acquisition of data. MGM and JW performed the statistical analysis.

Funding The work contained within this publication was supported by the Centers for Disease Control and Prevention (CDC), where technical assistance was provided through a federal cooperative agreement in the design and conduct of the study; collection, management, analysis and interpretation of the data; and preparation, review and approval of the manuscript.

Competing interests None.

Disclaimer The findings and conclusions in this article are those of the authors and do not necessarily represent the official position of the Centers for Disease Control and Prevention.

Patient consent Obtained.

Ethics approval The Institutional Review Boards at each site and the Centers for Disease Control and Prevention reviewed and approved the study protocol.

Provenance and peer review Not commissioned; externally peer reviewed.

Data sharing statement The Safe in the City Study Group has a projectspecific web site that provides additional details about the study and data. http://www.stdcentral.org/SitC/ (please click on 'contact' for additional information or to initiate a request). You may request data by emailing Kees. Rietmeijer@dhha.org.

Open Access This is an Open Access article distributed in accordance with the Creative Commons Attribution Non Commercial (CC BY-NC 4.0) license, which permits others to distribute, remix, adapt, build upon this work noncommercially, and license their derivative works on different terms, provided the original work is properly cited and the use is non-commercial. See: http:// creativecommons.org/licenses/by-nc/4.0/

\section{REFERENCES}

1. Weinstock H, Berman S, Cates W Jr. Sexually transmitted diseases among American youth: incidence and prevalence estimates, 2000. Perspect Sex Reprod Health 2004;36:6-10.

2. CDC. STD trends in the United States: 2010 national data for gonorrhea, chlamydia, and syphilis. November 2011. http://www.cdc. gov/std/stats10/trends.htm (accessed 6 Jul 2012).

3. Warner L, Gallo MF, Macaluso M. Condom use around the globe: how can we fulfill the prevention potential of male condoms? Sex Health 2012;9:4-9.
4. Lopez LM, Tolley EE, Grimes DA, et al. Theory-based interventions for contraception. Cochrane Database Syst Rev 2011;(3):CD007249.

5. Crepaz N, Marshall KJ, Aupont LW, et al. The efficacy of HIV/STI behavioral interventions for African American females in the United States: a meta-analysis. Am J Public Health 2009;99: 2069-78.

6. Jemmott LS, Jemmott JB, O'Leary A. Effects on sexual risk behavio and STD rate of brief HIV/STD prevention interventions for African American women in primary care settings. Am J Public Health 2007;97:1034-40.

7. Jemmott LS, Jemmott JB, Hutchinson MK, et al. Sexually transmitted infection/HIV risk reduction interventions in clinical practice settings. J Obstet Gynecol Neonatal Nurs 2008;37:137-45.

8. O'leary A. Self-efficacy and health-behavioral and stressphysiological mediation. Cogn Ther Res 1992;16:229-45.

9. Warner L, Klausner JD, Rietmeijer CA, et al. Effect of a brief video intervention on incident infection among patients attending sexually transmitted disease clinics. PLoS Med 2008;5:919-27.

10. Crosby R, Shrier LA, Charnigo RJ, et al. A prospective event-level analysis of condom use experiences following STI testing among patients in three US cities. Sex Transm Dis 2012;39:756-60.

11. Smith KW, McGraw SA, Costa LA, et al. A self-efficacy scale for HIV risk behaviors: development and evaluation. AIDS Educ Prev 1996;8:97-105.

12. Crosby RA, Diclemente RJ, Salazar LF, et al. Predictors of consistent condom use among young African American women. AIDS Behav 2013;17:865-7.

13. Bandura A. Social foundations of thought and action: a social cognitive theory. Englewood Cliffs, NJ: Prentice- Hall Inc, 1986.

14. Dilorio $\mathrm{C}$, Maibach $\mathrm{E}$, Oleary $\mathrm{A}$, et al. Measurement of condom use self-efficacy and outcome expectancies in a geographically diverse group of STD patients. AIDS Educ Prev 1997;9:1-13.

15. Peterson JL, Coates TJ, Catania J, et al. Evaluation of an HIV risk reduction intervention among African-American homosexual and bisexual men. AIDS 1996;10:319-25.

16. Hardnett FP, Pals SL, Borkowf CB, et al. Assessing mediation in HIV intervention studies. Public Health Rep 2009;124:288-94.

17. O'Leary A, Wolitski RJ, Remien RH, et al. Psychosocial correlates of transmission risk behavior among HIV-seropositive gay and bisexual men. AIDS 2005;19:S67-75.

18. LoConte JS, Oleary A, Labouvie E. Psychosocial correlates of HIV-related sexual behavior in an inner city STD clinic. Psychol Health 1997;12:589-601.

19. Fishbein M, Ajzen I. Belief, attitude, intention, and behavior: an introduction to theory and research. Reading, MA: Addison-Wesley, 1975.

20. Remien $\mathrm{RH}$, Halkitis PN, O'Leary A, et al. Risk perception and sexual risk behaviors among HIV-positive men on antiretroviral therapy. AIDS Behav 2005;9:167-76.

21. O'Leary A, Jemmott LS, Jernmott JB. Mediation analysis of an effective sexual risk-reduction intervention for women: the importance of self-efficacy. Health Psychol 2008;27:S180-4.

22. Kapadia F, Latka MH, Wu Y, et al. Longitudinal determinants of consistent condom use by partner type among young injection drug users: the role of personal and partner characteristics. AIDS Behav 2011:15:1309-18.

23. Catania JA, Gibson DR, Chitwood DD, et al. Methodological problems in AIDS behavioral research: influences on measurement error and participation bias in studies of sexual behavior. Psychol Bull 1990;108:339-62. 
Correction: Relationship between social cognitive theory

constructs and self-reported condom use: assessment of

behaviour in a subgroup of the Safe in the City trial

Snead MC, O'Leary AM, Mandel MG, et al. Relationship between social cognitive theory constructs and self-reported condom use: assessment of behaviour in a subgroup of the Safe in the City trial. BMJ Open 2014;4:e006093.

The trial registration number in this article is incorrect and should be: NCT00137370.

Open Access This is an Open Access article distributed in accordance with the Creative Commons Attribution Non Commercial (CC BY-NC 4.0) license, which permits others to distribute, remix, adapt, build upon this work noncommercially, and license their derivative works on different terms, provided the original work is properly cited and the use is non-commercial. See: http://creativecommons.org/licenses/by-nc/4.0/

BMJ Open 2016;6:e006093corr1. doi:10.1136/bmjopen-2014-006093corr1

CrossMark 